\title{
ABERRANT PROMOTER HYPERMETHYLATION OF SELECTED APOPTOTIC GENES IN CHILDHOOD ACUTE LYMPHOBLASTIC LEUKEMIA AMONG NORTH INDIAN POPULATION
}

\author{
M. Nikbakht ${ }^{1}$, A.K. Jha' ${ }^{2}$ K. Malekzadeh ${ }^{3}$, M. Askari', S. Mohammadi ${ }^{1}$, R.K. Marwaha ${ }^{5}$, D. Kaul', J. Kaur ${ }^{4}$ * \\ ${ }^{1}$ Hematology-Oncology and Stem Cell Transplantation Research Center, Tehran University of Medical Sciences, \\ Tehran 1411713131, Iran \\ ${ }^{2}$ Department of Biotechnology, IMS Engineering College, Ghaziabad (U.P.) 160012, India \\ ${ }^{3}$ Molecular Medicine Research Center (MMRC); Hormozgan University of Medical Science (HUMS); \\ Bandar Abbass 7919915519, Iran \\ ${ }^{4}$ Department of Biotechnology Panjab University, Chandigarh 160014, India \\ ${ }^{5}$ Advanced Pediatrics Center, PGIMER, Chandigarh 160014, India \\ ${ }^{5}$ Department of Experimental Medicine and Biotechnology, PGIMER, Chandigarh 160014, India
}

\begin{abstract}
Promoter hypermethylation mediates gene silencing in many neoplasms. Acute leukemia has been reported to harbor multiple genes aberrantly silenced by hypermethylation. Aim: In present study, we investigated the prevalence of hypermethylation of caspase-8 (CASP8), TMS1 and DAPK genes in correlation with clinicopathological factors in childhood acute lymphoblastic leukemia (ALL). Materials and Methods: A case-control study has been conducted based on bone marrow and peripheral blood samples from 125 ALL patients and 100 sex-age matched healthy controls. Methylation specific polymerase chain reaction (PCR) and bisulfite sequencing PCR was performed to analyze the methylation status of these genes. Reverse transcription PCR and real time PCR was carried out to determine changes in the mRNA expression level of the genes due to hypermethylation. Results: Hypermethylation of the ${ }^{\prime} \mathrm{CpG}$ islands of the CASP8, TMS1 and DAPK gene promoters was found in 3.2, 6.4, and 13.6\% of 125 childhood ALL samples from north Indian population, respectively. There were significant differences in pattern of hypermethylation of TMS1 $(p=0.045)$ and DAPK $(p<0.001)$ between patients and healthy controls. Down-regulation of mRNA expression was found in cases in which $C A S P 8, T M S 1$ and $D A P K$ were hypermethylated. Conclusions: The present study indicated the impact of hypermethylation-mediated inactivation of CASP8, TMS1 and DAPK genes, which is associated with risk of childhood ALL. This abnormality occurs in leukemogenesis and it may be used as a biomarker and for predicting the prognosis of ALL.
\end{abstract}

Key Words: acute lymphoblastic leukemia, epigenetics, hypermethylation, apoptotic genes.

Childhood acute lymphoblastic leukemia (ALL), clinically known as heterogeneous disorder, is caused by uncontrolled proliferation of immature B or T lymphoblasts. It was estimated to be the seventh most prevalent type of cancer accounting for $3 \%$ of the new cancer cases and also accounts for the ninth rank in causes of death among children. Epigenetics can be described as a stable alteration in gene expression potential that takes place during development and cell proliferation, without any change in gene sequence. In higher eukaryotes, DNA is methylated only at cytosines adjacent to guanosine in the $\mathrm{CpG}$ dinucleotide. This modification has important regulatory effects on gene expression, especially when involving CpGrich areas known as $\mathrm{CpG}$ islands (CGI) located in the promoter regions of many genes [1]. Hypermethylation of the CGl of gene promoter of tumor suppressor genes is one of the earliest and most frequent alterations leading to cancer. The specific patterns of CGI

Submitted: August 22, 2016.

*Correspondence: $\quad$ E-mail: jagsekhon@yahoo.com; m-nikbakht@sina.tums.ac.ir

Abbreviations used: ALL - acute lymphoblastic leukemia; BM - bone marrow; CGI - CpG islands; $\mathrm{Cl}$ - confidence interval; DAPK - deathassociated protein kinase 1; MSP-PCR - methylation specific PCR; $\mathrm{OR}$ - odds ratio; PCR - polymerase chain reaction; RT - reverse transcription; TMS - target of methylation-mediated silencing. hypermethylation may provide a useful signature for tumor diagnosis and prognosis [2]. Aberrant promoter hypermethylation of tumor suppressor genes (without any structural alteration) and its association with transcriptional inactivation is considered as an epigenetic mechanism in leukemia pathogenesis [3-5].

Death-associated protein kinase 1 (DAPK) is a $160 \mathrm{kDa} \mathrm{Ca}^{2+} /$ calmodulin dependent, cytoskeletalassociated protein kinase. It has been found that DAPK exerts an apoptotic effect by inside-out inactivation of integrin, thereby suppressing the matrix survival signal and activating a p53-dependent apoptosis pathway $[6,7]$. Several studies have suggested that loss of DAPK expression or methylation of CGI in DAPK promoter region may be characteristic of highly invasive or metastatic tumors [8]. More than 100 reports from different laboratories were published on DAPK gene methylation in various human tumors. Also based on other report several B-cell lymphoma cell lines have decreased or absent expression of DAPK RNA or protein [9]. This finding suggests that abnormal loss of DAPK expression could be associated with aberrant promoter region methylation, serving as an alternative to the genetic loss of a tumor-suppressor gene function by deletion or mutation [10,11].

TMS1 (target of methylation-mediated silencing, also known as ASC or PYCARD), is commonly silenced 
by methylation in human cancer cells. TMS1 was identified in a screen for downstream targets of methylationmediated gene silencing induced by overexpression of human DNA methyltransferase-1 [12]. Methylation pattern of TMS1 at the TMS1 locus as well as the expression of TMS1 in many cancer cell lines especially epithelial cancer cell lines has been shown by many research groups [12-16]. TMS1-induced apoptosis could be blocked with a dominant-negative caspase-9, but not a dominant-negative caspase-8, which suggested that it was a part of intrinsic mitochondrial signaling [17].

Caspase-8 gene (CASP8) located at human chromosome 2q33-q34 [18] is involved in the regulation of apoptosis and also in several non-apoptotic processes such as proliferation, differentiation, and NF-kB activation [19]. Caspase- 8 expression or function can be impaired in cancers by mutation, deletion, epigenetic silencing, alternative splicing or posttranscriptional mechanisms such as phosphorylation. A high methylation rate and thereby gene silencing for CASP8 in medulloblastoma has been reported recently $[20,21]$.

So, the aim of present study was to investigate the prevalence of hypermethylation of CASP8, TMS1 and $D A P K$ in correlation with clinicopathological factors in childhood ALL. Our results indicate that hypermethylation-mediated inactivation of caspase-8, TMS1 and DAPK is associated with the risk of childhood ALL and it could be used as a biomarker and prognostic marker in these patients.

\section{MATERIALS AND METHODS}

Sample collection. The bone marrow (BM) aspirate was collected from patients admitted to Hematology-Oncology ward, Advanced Pediatric Center, PGIMER, Chandigarh, India, at the time of initial diagnosis and prior to any treatment regimen. The study was approved by Institute Ethical Committee and informed consent was obtained from the guardians of all the patients recruited in the study. Diagnosis was based on standard hematological protocol according to WHO classification. For statistical analysis, children were grouped according to National Cancer Research Institute (NCRI) risk classification; the clinical characteristics of the leukemic patients and regional distribution among northern states of India are shown in Table 1 and 2, respectively. For controls, blood samples were obtained from healthy donors with respect to median and mean of sex and age of patients. Mononuclear cells were obtained from $\mathrm{BM}$ aspirate and blood samples by centrifugation on Ficoll-Histopaque (Sigma-Aldrich, St. Louis, Missouri, USA) density gradient and were used for DNA and RNA extraction.

DNA isolation. DNA was extracted from mononuclear cells of BM and blood using standard proteinase K (Sigma-Aldrich, St. Louis, Missouri, USA) digestion followed by phenol chloroform extraction and ethanol precipitation. The DNA concentration was determined by spectrophotometry and its integrity was checked by $1.5 \%$ agarose gel electrophoresis.
Table 1. Demographic and clinical characteristics of study population

\begin{tabular}{lcc}
\hline & Patients (N=125) & Control group (N = 100) \\
\hline & $\mathrm{n}(\%)$ & $\mathrm{n}(\%)$ \\
\hline Gender & & \\
Male & $97(77.6)$ & $77(77.0)$ \\
Female & $28(22.4)$ & $23(23.0)$ \\
Mean age, years ( \pm SD) & $6.46 \pm 3.34$ & $6.55 \pm 3.37$ \\
Age $<2$ & $12(9.6)$ & $11(11.0)$ \\
$2<$ age $<5$ & $43(34.4)$ & $33(33.0)$ \\
age $>5$ & $70(56.0)$ & $56(56.0)$ \\
Cell lineage & & \\
B-lineage ALL & $118(94.4)$ & - \\
T-lineage ALL & $7(5.6)$ & - \\
NCRI risk group & $103(82.4)$ & - \\
Standard & $22(17.6)$ & - \\
High & & \\
\hline
\end{tabular}

Table 2. Distribution of cases on the basis of regional distribution

\begin{tabular}{lc}
\hline \multicolumn{1}{c}{ State } & Patients $(\mathrm{n}=125), \%$ \\
\hline Punjab & 55 \\
Haryana & 34 \\
Uttar Pradesh & 16 \\
Himachal Peradesh & 10 \\
Chandigarh & 5 \\
Jammu \& Kashmir & 5 \\
\hline
\end{tabular}

Sodium bisulfite modification of DNA. Sodium bisulfite modification of genomic DNA was performed as described previously, with little modifications [1]. A sample of genomic DNA $(2 \mu \mathrm{g})$ was denatured with $\mathrm{NaOH}$ (final concentration 0.2 M) followed by incubation at $37^{\circ} \mathrm{C}$ for $10 \mathrm{~min}$. Then, DNA was modified by incubation with $30 \mu$ l of $10 \mathrm{mM}$ hydroquinone (Sigma-Aldrich, St. Louis, Missouri, USA). $520 \mu$ of freshly prepared $3 \mathrm{M}$ sodium bisulfite (Sigma-Aldrich, St. Louis, Missouri, USA) $(\mathrm{pH}=5)$ was added and the mixture was incubated at $50{ }^{\circ} \mathrm{C}$ for $16 \mathrm{~h}$. After incubation, modified DNA was purified using DNA Wizard Clean-up (Promega, Madison, Wisconsin, USA) according to manufacturer's procedure and eluted into $50 \mu$ of sterile water followed by desulfonation in $0.3 \mathrm{~N} \mathrm{NaOH}$ at $25^{\circ} \mathrm{C}$ for $5 \mathrm{~min}$. Desulfonated DNA was then precipitated with ammonium acetate and ethanol, washed with $70 \%$ ethanol and re-suspended in $20 \mu$ of sterile water.

Methylation specific polymerase chain reaction (MSP-PCR). MSP-PCR was used to study the methylation status of the $\mathrm{CGl}$ in promoter regions of CASP8, $T M S 1$ and $D A P K$. The reaction mixture $(50 \mu \mathrm{l})$ contained $2 \mu \mathrm{l}$ of above bisulfite-treated DNA, $0.2 \mathrm{mM}$ of dNTP (each at concentration $10 \mathrm{mM}$ ) (Fermentas Life Science, Waltham, Massachusetts, USA), $10 \rho \mathrm{M}$ of each primer (synthesized by Sigma), $5 \mu \mathrm{l}$ of BSA $(10 \mathrm{mg} / \mathrm{ml})$ (Sigma-Aldrich, St. Louis, Missouri, USA), 10X PCR buffer [ $750 \mathrm{mM}$ Tris- $\mathrm{HCl}$ (pH 8.8), $200 \mathrm{mM}\left(\mathrm{NH}_{4}\right)_{2} \mathrm{SO}_{4}$, $0.1 \%$ Tween [20], $2.5 \mathrm{mM} / \mathrm{I} \mathrm{MgCl}_{2}$, and 1 unit of thermostable Hot Start Taq DNA polymerase (Qiagen, Hilden, Germany). The primer sequence and PCR conditions are listed in Table 3. MSP-PCR products were analyzed by using $2 \%$ agarose gel electrophoresis followed by ethidium-bromide staining and visualized under UV transillumination.

Bisulfite sequencing. MSP-PCR products were gel purified (Sigma-Aldrich, St. Louis, Missouri, USA), sequenced by using $A B I$ prism Big-Dye terminator (Applied Biosystems, Foster City, California, USA) and analyzed on an automated DNA sequence anaIyzer (3700 ABI Prism, PE Biosystem) to determine the 
methylation status of $\mathrm{CpG}$ sites in the amplified regions. Treatment of genomic DNA with sodium bisulfate induces deamination of nonmethylated cytosine and converts it to uracil and finally to thymidine, but has no effect on methylated cytosine. This modification allows for differentiation of methylated and nonmethylated CGI in promoter region of tumor suppressor genes by MSP-PCR or sequencing. For this purpose, $5 \mu$ l of the bisulfite-treated DNA amplified by MSP-PCR was run on a $2 \%$ agarose gel and desired band was gel purified using Promega SV gel purification kit (Promega, Madison, Wisconsin, USA) and sent for sequencing using the $A B I$ prism Big-Dye Terminator Cycle Sequencing Ready Reaction Kit (Applied Biosystems, Foster City, CA) on an automated DNA sequence analyzer (3700 ABI Prism, PE Biosystem).

Table 3. Primer sequences, annealing temperatures and PCR product size used for MSP-PCR and reverse trascription PCR (RT-PCR)

\begin{tabular}{|c|c|c|c|c|}
\hline & Sequence $5^{\prime} \rightarrow 3^{\prime}$ & 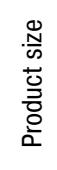 & 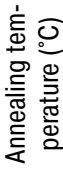 & 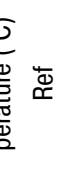 \\
\hline $\begin{array}{l}\text { CASP8 } \\
\text { methylated }\end{array}$ & $\begin{array}{l}\text { Forward: TAGGGGATTCGGAGATTGCGA } \\
\text { Reverse: CGTATATCTACATTCGAAACGA }\end{array}$ & 320 & 50 & [24 \\
\hline $\begin{array}{l}\text { CASP8 } \\
\text { nonmethylated }\end{array}$ & $\begin{array}{l}\text { Forward: TAGGGGATTTGGAGATTGTGA } \\
\text { Reverse: CCATATATCTACATTCAAAACAA' }\end{array}$ & 321 & 53 & \\
\hline $\begin{array}{l}\text { TMS1 } \\
\text { methylated }\end{array}$ & $\begin{array}{l}\text { Forward: CGATTTTGGCGTTTTTCGACGGTT } \\
\text { Reverse: CCGCTCACCCCGCTACAACCG C }\end{array}$ & 207 & 55 & \\
\hline $\begin{array}{l}\text { TMS1 } \\
\text { nonmethylated }\end{array}$ & $\begin{array}{l}\text { Forward: TTGTTGGAGGGTAATGGATT } \\
\text { Reverse: CCCACAAAAATACACCCATA }\end{array}$ & 272 & 58 & {$[3$} \\
\hline $\begin{array}{l}\text { DAPK } \\
\text { methylated }\end{array}$ & $\begin{array}{l}\text { Forward: GGATAGTCGGATCGAGTTAACGTC } \\
\text { Reverse: CCCTCCCAAACGCCGA }\end{array}$ & 321 & 63 & {$[2$} \\
\hline $\begin{array}{l}\text { DAPK } \\
\text { nonmethylated }\end{array}$ & $\begin{array}{l}\text { Forward: GGAGGATAGTTGGATTGAGTTAATGTT } \\
\text { Reverse: CAAATCCCTCCCAAACACCAA }\end{array}$ & 321 & 63 & \\
\hline $\begin{array}{l}\text { CASP8 } \\
\text { RT-PCR }\end{array}$ & $\begin{array}{l}\text { Forward: AGAGAAGCAGCAGCCTTGAAGG } \\
\text { Reverse: AGACAGTATCCCCGAGGTTTGC' }\end{array}$ & 160 & 55 & [2 \\
\hline $\begin{array}{l}\text { TMS1 } \\
\text { RT-PCR }\end{array}$ & $\begin{array}{l}\text { Forward: GGACGCCTTGGCCCTCACCG' } \\
\text { Reverse: GGCGCGGCTCCAGAGCCCTG' }\end{array}$ & 148 & 65 & {$[3$} \\
\hline $\begin{array}{l}\text { DAPK } \\
\text { RT-PCR }\end{array}$ & $\begin{array}{l}\text { Forward: GATAGAAATGTCCCCAAACCTCG' } \\
\text { Reverse: TCTTCTTTGGATCCTTGACCAGAA' }\end{array}$ & 280 & 55 & {$[2]$} \\
\hline $\begin{array}{l}\beta \text {-actin } \\
\text { RT-PCR }\end{array}$ & $\begin{array}{l}\text { Forward: CATGTACGTTGCTATCCAGGC } \\
\text { Reverse: CTCCTTAATGTCACGCACGAT }\end{array}$ & 254 & 58 & {$[2$} \\
\hline
\end{tabular}

Note: MSP-PCR conditions: $95^{\circ} \mathrm{C} / 5$ min followed by 35 cycle $95^{\circ} \mathrm{C} / 45 \mathrm{~s}$; annealing temp. $/ 30 \mathrm{~s} ; 72^{\circ} \mathrm{C} / 45 \mathrm{~s} ; 72^{\circ} \mathrm{C} / 10 \mathrm{~min} ; \mathrm{RT}-\mathrm{PCR}$ conditions: $94^{\circ} \mathrm{C} / 5 \mathrm{~min}$ followed by 35 cycle $95^{\circ} \mathrm{C} / 45 \mathrm{~s}$; annealing temp. $/ 30 \mathrm{~s} ; 72^{\circ} \mathrm{C} / 45 \mathrm{~s} ; 72^{\circ} \mathrm{C} / 7 \mathrm{~min}$.

RNA isolation. Total RNA was extracted using the TRI reagent (Sigma-Aldrich, St. Louis, Missouri, USA), according to the manufacturer's instructions. The RNA pellets were reconstituted in DEPC (SigmaAldrich, St. Louis, Missouri, USA) treated water. The quality of the RNA samples was determined by electrophoresis through denaturing agarose gels staining with ethidium bromide; the 18S and 28S RNA bands were visualized under transilluminator. The quality and quantity of total RNA was determined spectrophotometrically at 260 and $280 \mathrm{~nm}$.

$\boldsymbol{R T}$-PCR. Complementary DNAs (cDNAs) were reverse transcribed from 1-2 $\mu \mathrm{g}$ of total RNA by use of Revert Aid first strand cDNA synthesis kit (Fermentas Life Science, Waltham, Massachusetts, USA) according to the manufacturer's instructions. Briefly, $1 \mu \mathrm{l}(0.2 \mu \mathrm{g} / \mu \mathrm{l})$ of random hexamer primers was added to $1.5 \mu \mathrm{g}$ of total cellular RNA in a final volume of $12 \mu \mathrm{l}$ followed by addition of supplied $1 \mu \mathrm{l}$ MuLV reverse transcriptase. The reaction mixture was then incubated for $1 \mathrm{~h}$ at $42{ }^{\circ} \mathrm{C}$, followed by incubation at $70^{\circ} \mathrm{C}$ for $10 \mathrm{~min}$ and subsequently stored at $-20^{\circ} \mathrm{C}$.

Gel electrophoresis of the PCR products and graphs of melt curve and melt peak indicated that target genes could be specifically amplified using specific primers. The cDNA concentration was then normalized in series of PCR by using $\beta$-actin primers (see Table 3 ) and by carefully diluting cDNA until PCR products of different samples were similar to each other in band intensity using Scion analyzer software. The normalized cDNAs were subjected to amplification for detection of expression of MTS2 and MTS1 using gene specific primers for real-time RT-PCR.

Real-time PCR. Expression of genes was analyzed by quantitative real-time PCR using specific primer for each gene and SYBR Green Quantitative RT-PCR kit (Stratagene, Agilent Technology, USA). All samples were analyzed on the Stratagene Real Time Detector. $\beta$-Actin gene expression was used as invariant control to normalize input cDNA. Quantitative real-time RT-PCR was performed in a reaction volume of $20 \mu \mathrm{lin}$ cluding $1 \mu \mathrm{l}$ of cDNA. The comparative Ct method was used to compute relative expression values.

Statistical analysis. The data were analyzed by computing odds ratio (OR) and $95 \%$ confidence interval $(\mathrm{Cl})$ using $\chi^{2}$-test, Fisher exact test and multivariate logistic regression with adjustment for age as a continuous variable to find out any difference between cases and healthy controls according to age, gender, immunophenotypes, and NCRI risk group's classification. The reported OR can be interpreted as age-adjusted estimates of the relative risk of developing ALL with methylation of studied genes. Analysis of continuous data like age was done by one way ANOVA. Statistical analysis was performed using SPSS (Version 18, SPSS Inc, Chicago, IL, USA). The Mann - Whitney $U$ test was used to assess the significance of the difference in mRNA expression level of the individual genes and clinical stage. All $p$ values $<0.05$ were considered statistically significant.

\section{RESULTS}

The relevant characteristics of the study subjects are summarized in Table 1. In this study, samples from 125 patients with ALL and 100 healthy controls were collected. The cases and the controls were well matched with respect to age, sex and place of living. The mean age was $6.50 \pm 3.37$ years for cases and $6.40 \pm 3.33$ years for controls $(p=0.9) .9 .6 \%$ of patients were in the age-group of $0-2$ years, $43.4 \%$ were in the age-group of $2-5$ years and $56.0 \%$ in age group of more than 5 years old. The percent of males and females among cases and controls were 77.6:77.0 for males and 22.4:23.0 for females, respectively.

The cell lineages and NCRI risk groups of ALL patients are also presented in Table 1. 94.4\% of patients were diagnosed with B-lineage ALL and 5.6\% with T-lineage ALL. The patients were stratified into two risk groups according to the protocol of National Cancer Institute: (i) the high-risk category included 
patients less than one year or more than 9 years old who had a white blood cells count of more than $50,000 / \mu \mathrm{l}$ at the time of diagnosis (ii) the standardrisk category included patients aged 1 to 9 years who had a white blood cells count of less than $50,000 / \mu \mathrm{l}$ at the time of diagnosis. All children with T-lineage ALL were considered at high risk regardless of age and initial white blood cells count. The distribution of ALL patients on the basis of NCRI risk groups were $82.4 \%$ in standard risk group and $17.6 \%$ in high risk group.

Study of the methylation status of apoptotic genes. Bisulfite-treated DNA from all 125 ALL patients was analyzed for CASP8, TMS1 and DAPK promoter hypermethylation by standard MSP-PCR technique. Primers for this technique were designed to be located within the promoter region associated CGI and near the major MSP-PCR analysis of the CASP8, TMS1 and DAPK promoters in samples using defined nonmethylated and methylated specific primers. The frequency of methylation pattern of CASP8, TMS1 and DAPK genes has been depicted in Table 4. Methylation of CASP8 was found in $3.2 \%$ of patients. Significant risk of ALL development was not observed in patients with hypermethylated CASP8 promoter $(p>0.05)$. Methylation of TMS1 was found in $6.4 \%$ of patients. Statistically significant difference in methylation of TMS1 $(p=0.045)$ between patients and controls was observed. Risk of ALL increased by 1.64 fold with hypermethylated TMS1 promoter $(\mathrm{OR}=1.64,95 \% \mathrm{Cl}=1.26-2.13)$. Methylation of $D A P K$ was found in $13.6 \%$ of patients. Statistically significant difference in methylation of DAPK $(p<0.001)$ between patients and controls was observed. Significant risk of ALL development was evident in patients with hypermethylated $D A P K$ promoter $(p<0.01 ; \mathrm{OR}=1.93,95 \% \mathrm{Cl}=1.69-2.19)$ (see Table 4).

Table 4. Frequency of methylation with risk of ALL (patients vs healthy control)

\begin{tabular}{ccccc}
\hline \multirow{2}{*}{ Genes } & $\begin{array}{c}\text { Patients } \\
(\mathrm{N}=125), \mathrm{n}(\%)\end{array}$ & $\begin{array}{c}\text { Control } \\
\text { (N = 100), } \mathrm{n}(\%)\end{array}$ & $\mathrm{OR}(95 \% \mathrm{Cl})$ & $p$ \\
\hline \multicolumn{5}{c}{ Presence of methylation } \\
CASP8 & $4(3.2)$ & $0(0.0)$ & $1.83(1.62-2.06)$ & 0.13 \\
TMS1 & $8(6.4)$ & $1(1.0)$ & $1.64(1.26-2.13)$ & 0.045 \\
DAPK & $17(13.6)$ & $0(0.0)$ & $1.93(1.69-2.19)$ & 0.001 \\
\hline
\end{tabular}

The frequency of methylation of CASP8, TMS1 and $D A P K$ was further analyzed according to selected clinicopathological features in ALL patients (Table 5). Hypermethylation of CASP 8 and $D A P K$ was observed in 4.1 and $12.4 \%$ and hypermethylation of TMS1 was observed in $5.15 \%$ of male ALL patients. Statistically significant difference in methylation of $D A P K$ $(p<0.01)$ between male ALL patients and controls was evident. Hypermethylation of CASP8 was observed in $4.8 \%$ of male patients, methylated promoter was not detected in female patients. Statistically significant difference in methylation of CASP8 $(p=0.045)$ between male ALL patients and controls was observed $(\mathrm{OR}=2.08,95 \% \mathrm{Cl}=1.79-2.4)$. Hypermethylation of TMS1 was detected in $5.15 \%$ of male patients and $10.7 \%$ of female patients. Methylation of TMS1 gene in association with gender was not statistically significant among ALL patients. Hypermethylation of DAPK was detected in $12.4 \%$ of male patients and $17.9 \%$ of female patients. Methylation of DAPK gene was statistically significant in male and female ALL patients as compared to controls. The risk of ALL due to hypermethylation of $D A P K$ increased around 1.9 fold in male patients and 2.00 fold in female patients $(\mathrm{OR}=1.91$, $95 \% \mathrm{Cl}=1.65-2.21$ for male and $\mathrm{OR}=2.00,95 \% \mathrm{Cl}=$ 1.50-2.67 for female patients) (Table 5).

The methylation of CASP8, TMS1 and DAPK in association with cell lineage of ALL patients is presented in Table 6. Statistically significant relation was not evident among these two groups.

Table 6. The frequency and percentage of hypermethylation in promoter of genes with B- or T-lineage ALL

\begin{tabular}{ccccc}
\hline Genes & $\begin{array}{c}\mathrm{B} \text {-lineage ALL } \\
(\mathrm{N}=118), \mathrm{n}(\%)\end{array}$ & $\begin{array}{c}\mathrm{T} \text {-lineage } \mathrm{ALL} \\
(\mathrm{N}=7), \mathrm{n}(\%)\end{array}$ & OR $(95 \% \mathrm{Cl})$ & $p$ \\
\hline \multicolumn{5}{c}{ Presence of methylation } \\
CASP8 & $4(3.3)$ & - & $1.06(1.02-1.11)$ & 1 \\
TMS1 & $6(5.1)$ & $2(28.57)$ & $0.80(0.52-1.17)$ & 0.06 \\
DAPK & $16(13.6)$ & $1(14.2)$ & $1.00(0.88-1.13)$ & 1 \\
\hline
\end{tabular}

The frequency of methylation of these genes in patients with stratified age groups, namely Age $<2$ and $2<$ Age $\leqslant 5$, Age $>5$ are presented in Table 5 . Hypermethylation of CASP 8 was not observed among patients with age $<2$ years. For age group $2<$ Age $\leqslant 5$ hypermethylation was $2.3 \%$ and for Age $>5$ it was $4.28 \%$. Methylation of CASP 8 was not statistically significant in patients with any of these age groups $(p>$ $0.05)$. The percentage of methylated TMS1 was $8.3 \%$ in patients of Age $<2,7 \%$ in patients of $2<$ Age $\leqslant 5$ and $5.7 \%$ in patients of Age $>5$. Methylation of TMS 1 was not statistically significant in patients of all of these age groups. The percentage of methylated $D A P K$ was $16.6 \%$ in patients of Age $<2$ years, $11.63 \%$ in patients of $2<$ Age $\leqslant 5$, and $14.28 \%$ in patients of Age $>5$. Statistically significant association between methylation of $D A P K$ gene and development of ALL in patients of age $>5$ years as compared to healthy controls was evident $(\mathrm{OR}=1.93,95 \% \mathrm{Cl}=1.62-2.30)$ (see Table 5).

The frequency of methylation of CASP8, TMS1 and $D A P K$ in relation to $\mathrm{NCRI}$ risk is shown in Table 7. Hy-

Table 5. Methylation status of genes with respect to clinicopathological features in childhood ALL patients from North India

\begin{tabular}{|c|c|c|c|c|c|c|c|c|c|c|c|c|}
\hline & \multicolumn{4}{|c|}{ CASP8 } & \multicolumn{4}{|c|}{ TMS1 } & \multicolumn{4}{|c|}{ DAPK } \\
\hline & $\begin{array}{r}\text { Pres } \\
\text { of meth }\end{array}$ & $\begin{array}{l}\text { ence } \\
\text { iylation }\end{array}$ & & & $\begin{array}{r}\text { Pres } \\
\text { of metl }\end{array}$ & $\begin{array}{l}\text { ence } \\
\text { ylation }\end{array}$ & & & $\begin{array}{r}\text { Prese } \\
\text { of meth }\end{array}$ & $\begin{array}{l}\text { ence } \\
\text { ylation }\end{array}$ & & \\
\hline & $\begin{array}{c}\text { Patients, } \\
n(\%)\end{array}$ & $\begin{array}{c}\text { Control, } \\
n(\%)\end{array}$ & OR (95\% Cl) & $p$ & $\begin{array}{c}\text { Patients, } \\
n(\%)\end{array}$ & $\begin{array}{c}\text { Control, } \\
n(\%)\end{array}$ & OR (95\% Cl) & $p$ & $\begin{array}{c}\text { Patients, } \\
\mathrm{n}(\%)\end{array}$ & $\begin{array}{c}\text { Control, } \\
\mathrm{n}(\%)\end{array}$ & OR (95\% Cl) & $p$ \\
\hline Male & $4(4.1)$ & - & $2.08(1.79-2.40)$ & 0.05 & $5(5.2)$ & $1(1.2)$ & $1.52(1.04-2.23)$ & 0.22 & $12(12.4)$ & - & $1.91(1.65-2.21)$ & - \\
\hline Female & - & - & - & - & $3(10.7)$ & - & $1.92(1.46-2.52)$ & 0.24 & $5(17.9)$ & - & $2.00(1.50-2.67)$ & 0.05 \\
\hline Age $<2$ & - & - & - & - & $1(8.3)$ & - & $2.00(1.31-3.04)$ & 1 & $2(16.6)$ & - & $2.10(1.34-3.29)$ & 0.47 \\
\hline $2<$ Age $<5$ & $1(2.3)$ & - & $1.79(1.46-2.18)$ & 1 & $3(7.0)$ & $1(3.0)$ & $1.35(0.74-2.47)$ & 0.62 & $5(11.6)$ & - & $1.84(1.50-2.32)$ & 0.06 \\
\hline Age $>5$ & $3(4.3)$ & - & $1.84(1.56-2.16)$ & 0.25 & $4(5.7)$ & - & $1.85(1.57-2.18)$ & 0.12 & $10(14.3)$ & - & $1.93(1.62-2.30)$ & - \\
\hline
\end{tabular}


permethylation of CASP8, TMS1 and DAPK was not found to be statistically significant in patients of standard and high risk groups $(p>0.05)$.

Table 7. The frequency of methylation of genes and NCRI risk groups of ALL patients

\begin{tabular}{ccccc}
\hline Genes & $\begin{array}{c}\text { Standard } \\
(\mathrm{N}=103), \mathrm{n}(\%)\end{array}$ & $\begin{array}{c}\text { High } \\
\mathrm{N}=22), \mathrm{n}(\%)\end{array}$ & OR $(95 \% \mathrm{Cl})$ & $p$ \\
\hline \multicolumn{5}{c}{ Presence of methylation } \\
CASP8 & $3(2.9)$ & $1(4.5)$ & $0.91(0.51-1.61)$ & 0.5 \\
TMS1 & $6(5.6)$ & $2(9.0)$ & $0.90(0.60-1.36)$ & 0.06 \\
DAPK & $13(12.6)$ & $4(18.1)$ & $0.92(0.70-1.21)$ & 0.49 \\
\hline
\end{tabular}

Bisulfite sequencing analysis. Treatment of genomic DNA with sodium bisulfate induces deamination of nonmethylated cytosine, and converting it first to uracil and finally to thymidine, but has no effect on methylated cytosine. This modification allows differentiation of methylated and non-methylated CGI in promoter region of tumor suppressor genes by MSP-PCR or sequencing (Fig. 1, 2). The bisulfite sequencing analysis of those samples, which were hypermethylated in their promoter region of these genes as compared with wild type (nonmethylated promoter region) revealed conversion of methylated cytosine, but not nonmethylated cytosine, which subsequently led to down-regulation of gene expression.
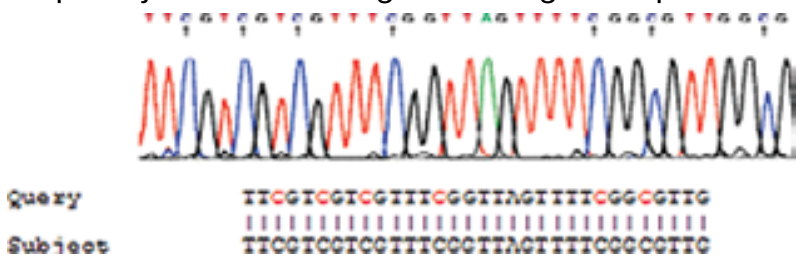

Fig. 1. Result of bisulfite sequence of DAPK

ICTCOCCCOSCCOCCAAACCTAAATAAACOATAAACCTASCCCQCCOCTAC

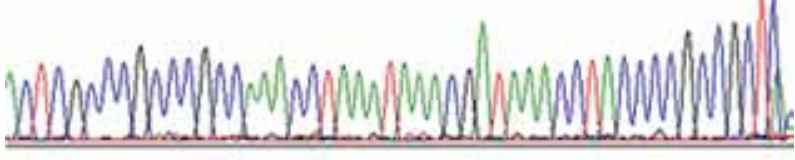

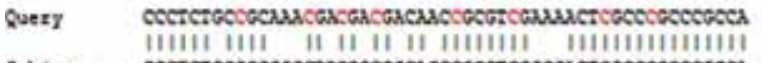

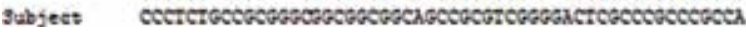

Fig. 2. Result of bisulfite sequence of TMS1

Study on the effect of promoter methylation on gene expression by $\boldsymbol{R T}$-PCR. The differences in CASP8, TMS1 and DAPK gene expression in ALL patients between methylated and nonmethylated studied genes are presented in Table 8. The transcription of these genes was significantly reduced in patients with methylated promoter $(p<0.001)$ in comparison to patients with nonmethylated promoter. Methylation resulted in up to $7.5 \%$ downregulation in transcription for CASP8, 22.08\% for TMS1 and $29.5 \%$ for DAPK. A significant reduction in the mRNA level in relation to patients with selected clinicopathological features in ALL patients $(p<$ 0.05) was observed.

Quantitative RT-PCR. The real time analysis of methylated and nonmethylated samples confirmed the result of RT-PCR. The hypermethylation of promoter region of CASP8, TMS 1 and DAPK resulted in their transcriptional down-regulation by approximately 0.95 -fold, 1.95 -fold and 2.85 -fold, respectively.

Table 8. The impact of promoter hypermethylation on expression genes in transcription level among patients of ALL

\begin{tabular}{ccccc}
\hline Genes & $\begin{array}{c}\text { Nonmethy- } \\
\text { lated, Mean } \\
( \pm \text { SE })\end{array}$ & $\begin{array}{c}\text { Methylated, } \\
\text { Mean }( \pm S E)\end{array}$ & $\begin{array}{c}\text { Down-regula- } \\
\text { tion, } \%\end{array}$ & $p$ \\
\hline CASP8 & $0.748( \pm 0.01)$ & $0.691( \pm 0.01)$ & 7.58 & 0.03 \\
TMS1 & $0.801( \pm 0.02)$ & $0.667( \pm 0.01)$ & 22.08 & 0.001 \\
DAPK & $0.866( \pm 0.02)$ & $0.610( \pm 0.05)$ & 29.50 & 0.001 \\
\hline
\end{tabular}

\section{DISCUSSION}

The present study was carried out to investigate epigenetic changes like promoter hypermethylation of tumor suppressor genes like CASP8, TMS1 and $D A P K$ with respect to different clinicopathological factors in childhood ALL within the population under study. CASP8 encodes an initiator caspase that plays an important role in the Fas-Fas ligand pathway [22, 23]. Alterations of these genes have been described in several neoplasia, like neuroblastoma and medulloblastoma [19, 24]. Harada et al. [25] observed frequent methylation of CASP8 in pediatric rhabdomyosarcomas, medulloblastomas, retinoblastomas and neuroblastomas. The frequency of hypermethylated CASP8 was found to be low in Wilms tumors and they could not observe any aberrant methylation of CASP8 in hepatoblastomas, acute leukemias, osteosarcomas and ganglioneuromas and also in healthy controls.

Harada et al. [25] reported the absence of methylation of CASP8 in Ewing sarcoma tumors. In contrast, Fulda et al. [26] showed around 65\% methylation of CASP8 in Ewing sarcoma. CASP8 as reported by other research group was methylated and inactivated in neuroendocrine lung carcinomas (small cell and bronchial carcinoids) but not in non-small cell carcinomas [27]. Also, hypermethylation-mediated down-regulation of caspase-8 has been reported by Wu et al. [28]. Structurally, the promoter region of CASP8 has binding sites for p53, NF-kB, AP-1, SP-1, IRF-1, and Ets-like transcription factors [29]. Therefore, caspase- 8 functions both as a pivotal molecule for death-receptor-induced apoptosis and as a selective signal transducer, such as for $N F-\kappa \beta$ activation [30]. Absence or down-regulation of caspase- 8 could cause resistance to apoptosis and correlated with unfavorable disease outcome, such as in childhood medulloblastoma and neuroblastoma [31, 32].

Till now, very few investigations of hematological malignancies have focused on CASP8 promoter hypermethylation. As caspase-8 mRNA was downregulated or silenced in the other malignancies, the possibility of promoter hypermethylation induced caspase-8 transcriptional silencing was investigated in the present study. It was observed that the distribution pattern of methylation was different among male ALL patients as compared with healthy controls $(p<0.05)$. These results revealed significant trend towards increasing risk of ALL with methylation of CASP 8 in male 
patient samples as compared with healthy controls. To the best of our knowledge, there are no reports on correlation of $C A S P 8$ hypermethylation in childhood ALL. Overall, the hypermethylation of CASP8 in association with age of patient did not show any impact in development and increasing risk of childhood ALL in our population under study. The cell lineage of ALL does not have any impact on methylation pattern of CASP8 in our population under study $(p>0.05)$. The bisulfite sequencing results confirm the MSP-PCR data. Regarding the distribution pattern of methylated CGI, no significant pattern was found in this study. The low level of down-regulation of mRNA expression of caspase-8 (7.58\%) was due to aberrant promoter methylation in childhood ALL. In the quantitative study of transcription with real time PCR, 0.95-fold downregulation of caspase- 8 was observed.

TMS1 is commonly silenced by methylation in human cancer cells. TMS1 down-regulation is induced by overexpression of human DNA methyltransferase-1 [12]. Methylation pattern of TMS1 and its effect on the mRNA expression of TMS1 in so many cancer cell lines especially, epithelial cancer cell lines have been shown by many research groups [12,33]. Methylation of the promoter region of TMS1/ASC has been reported in small cell lung cancer and non-small cell lung cancer [34], glioblastoma [35], ovarian, colorectal and prostate cancer [33, 36, 37]. In the present study, hypermethylation of TMS1 was found in 8 out of 125 (6.5\%) ALL patients, which was marginally significant. Our result was contrary to the report of RomanGomez et al. [38] in ALL patients. Our data revealed no significant trend towards increasing risk of ALL with methylation of TMS1 gene in both genders among the patient samples as compared with healthy controls $(p>0.05)$. The hypermethylation of TMS1 in association with the age of patients did not show any impact in development of childhood ALL in the north Indian population $(p>0.05)$. This finding was in consistency with the report of Roman-Gomez et al. [38]. Our data indicated that cell lineage of ALL does not have any impact on methylation pattern of TMS1 in the population under study $(p>0.05)$. It might be assumed that the methylation pattern of TMS1 in standard risk group and high risk group could not be used as a potential biomarker in risk of ALL. Interestingly, 22.8\% downregulation of TMS1 mRNA expression was observed in our population under study. In the quantitative study of transcription using real time PCR, 1.95-fold down-regulation of TMS1 was observed. The analysis of the results of semiquantitative and quantitative PCR showed the effect of hypermethylated promoter in down-regulation of TMS1. Furthermore, it is also involved in an intrinsic p53-dependent apoptotic checkpoint [39].

DAPK has been shown to be involved in normal cell differentiation and loss of the DAPK gene expression was reported in some malignancies as well as cancerous cell lines [8, 9]. Clinically, loss of DAPK expression, and therefore, absence of apoptosis in tumor cells could be considered as a biomarker of disease progression [40]. The promoter region of the DAPK contains a CGI that has been shown to be hypermethylated in solid tumors like squamous cell carcinoma of neck in $67 \%$ in German population.

Apoptosis is one of the hallmarks of cancer [41]. $D A P K$ is an important pro-apoptotic gene inactivated in many tumor types. Several studies of DAPK inactivation in lung cancers have been published [42-45] in which hypermethylation of the DAPK promoter was shown to be associated with loss of expression [4547]. Although limited number of reports is available, attempts were made to find out the profile of $D A P K$ promoter hypermethylation in childhood ALL in the present study. The results were shown to be completely in contrast to each other in different ethnic groups. It has been reported that $D A P K$ promoter was approximately $17 \%$ hypermethylated in adult and $\sim 10 \%$ in childhood ALL in Hispanic children [38]. In contrast, DAPK promoter was not hypermethylated in T-ALL samples of Dutch population [45]. Also, it has been reported from Japanese childhood ALL that in none of the samples DAPK was hypermethylated [48]. Aberrant $D A P K$ transcription has been reported in leukemia and lymphoma [38]. It was demonstrated that the down-regulation of expression of DAPK gene resulting from aberrant gene promoter hypermethylation was associated with disease progression in hematological malignancies $[49,50]$.

In present work, an attempt has been made to study the involvement of DAPK in clinicopathological process of ALL. As DAPK transcription was down-regulated in some of the ALL samples analyzed in this study, the possibility of promoter hypermethylation induced $D A P K$ transcriptional down-regulation was therefore investigated. It was observed that hypermethylation of DAPK was present in 17 out of 125 (13.6\%) ALL patients. This is in consistency with the other reports of Roman-Gomez et al. and Chim et al. [38, 51]. Significant effect of DAPK hypermethylation was observed in their population of study. The hypermethylation of $D A P K$ in both the genders increased the risk of childhood ALL, but no significant trend towards risk of ALL was observed in our population under study. No significant difference in aberrant methylation of $D A P K$ promoter could be observed in all age groups $(p>0.05)$. Also we assume that the methylation pattern of DAPK in standard risk group and high risk group did not have any impact towards the increasing risk of ALL in studied population. Unlike other groups which in their reports did not mention percentage of down-regulation for DAPK it was tried to find out the percentage of down-regulation of hypermethylated promoter of DAPK for each variable of study separately and this was done on the basis of statistical calculation to find out the correlation between each variable and expression of DAPK gene. In the present study, $19 \%$ down-regulation of DAPK was observed. In the quantitative study of transcription with real time PCR, 2.85-fold down-regulation of DAPK was observed. 
The analysis of result of semiquantitative and quantitative RT-PCR showed the effect of hypermethylated promoter in down-regulation of $D A P K$. It was demonstrated that the down-regulation of mRNA expression of $D A P K$ by its aberrant promoter hypermethylation could be considered as one of the factors affecting the $D A P K$ transcription.

In this study, we tried to detect the relation among the apoptotic genes which have been selected for this study with respect to variables. In our set of ALL samples, the most common situation is the simultaneous absence of methylation in both promoters but after this, the possible scenarios (CASP8 methylated alone, TMS1 methylated alone, DAPK methylated alone, CASP8, TMS1 both methylated or CASP8, DAPK both methylated and CASP8 and DAPK both methylated) are similarly represented. In ALL, hypermethylation in the promoter of these genes was an independent event. In the present study, an attempt was made to detect the relation among the apoptotic genes which have been selected for this study with respect to variable of study of interaction between CASP8 and TMS1. Association in the risk of ALL for each variable of study even when the both the genes were methylated was not detected. Also in interaction between CASP8 and $D A P K$, no association was found even when both the genes were methylated simultaneously. In the study of interaction between DAPK and TMS1 no association was observed. Significant correlation in interaction among this gene family was not observed. From these results it has been deduced that the hypermethylation in promoter region of these genes was independent to each other. The present findings need to be extended to a larger series.

To sum up, our results showed no significant role of caspase- 8 as a tumor suppressor gene in pathogenesis of ALL in north Indian population. Aberrant promoter hypermethylation of DAPK and TMS1 as tumor suppressor genes may support the role in pathogenesis and increase the risk of ALL in north Indian population. The methylation status of the DAPK and TMS1 genes might be considered as a predictive factor in the clinical outcome of ALL.

\section{REFERENCES}

1. Herman JG, Graff JR, Myohanen S, et al. Methylationspecific PCR: a novel PCR assay for methylation status of CpG islands. Proc Natl Acad Sci U S A 1996; 93: 9821-6.

2. Malekzadeh K, Sobti RC, Nikbakht M, et al. Methylation patterns of Rb1 and Casp-8 promoters and their impact on their expression in bladder cancer. Cancer Invest 2009; 27: 70-80.

3. Pui CH, Relling MV, Downing JR. Acute lymphoblastic leukemia. N Engl J Med 2004; 350: 1535-48.

4. Sinnett D, Krajinovic M, Labuda D. Genetic susceptibility to childhood acute lymphoblastic leukemia. Leuk Lymphoma 2000; 38: 447-62.

5. Lichtman MA. Williams hematology. New York: McGraw-Hill, 2006.

6. Wang WJ, Kuo JC, Yao CC, Chen RH. DAP-kinase induces apoptosis by suppressing integrin activity and disrupting matrix survival signals. J Cell Biol 2002; 159: 169-79.
7. Raveh T, Berissi H, Eisenstein M, et al. A functional genetic screen identifies regions at the $\mathrm{C}$-terminal tail and death-domain of death-associated protein kinase that are critical for its proapoptotic activity. Proc Natl Acad Sci U S A 2000; 97: 1572-7.

8. Simpson DJ, Clayton RN, Farrell WE. Preferential loss of death associated protein kinase expression in invasive pituitary tumours is associated with either $\mathrm{CpG}$ island methylation or homozygous deletion. Oncogene 2002; 21: 1217-24.

9. Kissil JL, Feinstein E, Cohen O, et al. DAP-kinase loss of expression in various carcinoma and B-cell lymphoma cell lines: possible implications for role as tumor suppressor gene. Oncogene 1997; 15: 403-7.

10. Katzenellenbogen RA, Baylin SB, Herman JG. Hypermethylation of the DAP-kinase $\mathrm{CpG}$ island is a common alteration in B-cell malignancies. Blood 1999; 93: 4347-53.

11. Baylin SB, Herman JG, Graff JR, et al. Alterations in DNA methylation: A fundamental aspect of neoplasia. Adv Cancer Res 1998; 72: 141-96.

12. Conway KE, McConnell BB, Bowring CE, et al. TMS1, a novel proapoptotic caspase recruitment domain protein, is a target of methylation-induced gene silencing in human breast cancers. Cancer Res 2000; 60: 6236-42.

13. Virmani A, Rathi A, Sugio K, et al. Aberrant methylation of TMS1 in small cell, non small cell lung cancer and breast cancer. Int J Cancer 2003; 106: 198-204.

14. Yokoyama T, Sagara J, Guan X, et al. Methylation of ASC/ TMS1, a proapoptotic gene responsible for activating procaspase-1, in human colorectal cancer. Cancer Lett 2003; 202: 101-8.

15. Akahira J, Sugihashi Y, Ito K, et al. Promoter methylation status and expression of TMS1 gene in human epithelial ovarian cancer. Cancer Sci 2004; 95: 40-3.

16. Liu XF, Tang K, Yu SP, et al. Correlation between promoter methylation of p14(ARF), TMS1/ASC, and DAPK, and p53 mutation with prognosis in cholangiocarcinoma. World J Surg Oncol 2012; 10: 5.

17. McConnell BB, Vertino PM. Activation of a caspase9-mediated apoptotic pathway by subcellular redistribution of the novel caspase recruitment domain protein TMS1. Cancer Res 2000; 60: 6243-7.

18. Kischkel FC, Kioschis $\mathbf{P}$, Weitz $\mathbf{S}$, et al. Assignment of CASP8 to human chromosome band $2 \mathrm{q} 33 \rightarrow \mathrm{q} 34$ and Casp8 to the murine syntenic region on chromosome 1B-proximal C by in situ hybridization. Cytogen Cell Genet 1998; 82: 95-6.

19. Teitz T, Wei T, Valentine MB, et al. Caspase 8 is deleted or silenced preferentially in childhood neuroblastomas with amplification of MYCN. Nature Med 2000; 6: 529-35.

20. Hadano S, Yanagisawa Y, Skaug J, et al. Cloning and characterization of three novel genes, ALS2CR1, ALS2CR2, and ALS2CR3, in the juvenile amyotrophic lateral sclerosis (ALS2) critical region at chromosome 2q33-q34: candidate genes for ALS2. Genomics 2001; 71: 200-13.

21. Zuzak TJ, Steinhoff D, Sutton L, et al. Loss of caspase- 8 mRNA expression is common in childhood primitive neuroectodermal brain tumour/medulloblastoma. Eur J Cancer 2002; 38: 83-91.

22. Steller H. Artificial death switches: Induction of apoptosis by chemically induced caspase multimerization. Proc Natl Acad Sci U S A 1998; 95: 5421-2.

23. Wolf BB, Green DR. Suicidal tendencies: Apoptotic cell death by caspase family proteinases. J Biol Chem 1999; 274: 20049-52.

24. Gonzalez-Gomez P, Bello MJ, Inda MM, et al. Deletion and aberrant $\mathrm{CpG}$ island methylation of Caspase 8 gene in medulloblastoma. Oncol Reports 2004; 12: 663-6. 
25. Harada K, Toyooka S, Shivapurkar N, et al. Deregulation of caspase 8 and 10 expression in pediatric tumors and cell lines. Cancer Res 2002; 62: 5897-901.

26. Fulda S, Kufer MU, Meyer E, et al. Sensitization for death receptor- or drug-induced apoptosis by re-expression of caspase- 8 through demethylation or gene transfer. Oncogene 2001; 20: 5865-77.

27. Shivapurkar N, Toyooka S, Eby MT, et al. Differential inactivation of caspase- 8 in lung cancers. Cancer Biol Ther 2013; 1: 65-9.

28. Wu YY, Alvarez M, Slamon DJ, et al. Caspase 8 and maspin are downregulated in breast cancer cells due to $\mathrm{CpG}$ site promoter methylation. BMC Cancer 2010; 10: 32.

29. Liedtke C, Groger N, Manns MP, Trautwein C. The human caspase- 8 promoter sustains basal activity through SP1 and ETS-like transcription factors and can be up-regulated by a p53-dependent mechanism. J Biol Chem 2003; 278: 27593-604.

30. Chaudhary PM, Eby MT, Jasmin A, et al. Activation of the NF-kappa B pathway by Caspase 8 and its homologs. Oncogene 2000; 19: 4451-60.

31. Pingoud-Meier C, Lang D, Janss AJ, et al. Loss of caspase- 8 protein expression correlates with unfavorable survival outcome in childhood medulloblastoma. Clin Cancer Res 2003; 9: 6401-9.

32. Yang QW, Kiernan CM, Tian YF, et al. Methylation of CASP8, DCR2, and HIN-1 in neuroblastoma is associated with poor outcome. Clin Cancer Res 2007; 13: 3191-7.

33. Das PM, Ramachandran K, VanWert J, et al. Methylation mediated silencing of TMS1/ASC gene in prostate cancer. Mol Cancer 2006; 5: 28.

34. Virmani A, Rathi A, Sugio K, et al. Aberrant methylation of TMS1 in small cell, non small cell lung cancer and breast cancer. Int J Cancer 2003; 106: 198-204.

35. Stone AR, Bobo W, Brat DJ, et al. Aberrant methylation and down-regulation of TMS1/ASC in human glioblastoma. Am J Pathol 2004; 165: 1151-61.

36. Terasawa K, Sagae S, Toyota M, et al. Epigenetic inactivation of TMS1/ASC in ovarian cancer. Clin Cancer Res 2004; 10: 2000-6.

37. Yokoyama T, Sagara J, Guan X, et al. Methylation of ASC/TMS1, a proapoptotic gene responsible for activating procaspase-1, in human colorectal cancer. Cancer Lett 2003; 202: $101-8$.

38. Roman-Gomez J, Jimenez-Velasco A, Castillejo JA, et al. Promoter hypermethylation of cancer-related genes: a strong independent prognostic factor in acute lymphoblastic leukemia. Blood 2004; 104: 2492-8.

39. Raveh T, Droguett G, Horwitz MS, et al. DAP kinase activates a p19(ARF)/p53-mediated apoptotic checkpoint to suppress oncogenic transformation. Nature Cell Biol 2001; 3: 1-7.

40. Shiramizu B, Mick P. Epigenetic changes in the DAPkinase $\mathrm{CpG}$ island in pediatric lymphoma. Med Pediatr Oncol 2003; 41: 527-31.

41. Hanahan D, Weinberg RA. The hallmarks of cancer. Cell 2000; 100: 57-70.

42. Esteller M, Sanchez-Cespedes M, Rosell R, et al. Detection of aberrant promoter hypermethylation of tumor suppressor genes in serum DNA from non-small cell lung cancer patients. Cancer Res 1999; 59: 67-70.

43. Kim DH, Nelson HH, Wiencke JK, et al. Promoter methylation of DAP-kinase: association with advanced stage in non-small cell lung cancer. Oncogene 2001; 20: 1765-70.

44. Tang X, Khuri FR, Lee JJ, et al. Hypermethylation of the death-associated protein (DAP) kinase promoter and aggressiveness in stage I non-small-cell lung cancer. $\mathbf{J}$ Natl Cancer Inst 2000; 92: 1511-6.

45. Zochbauer-Muller S, Fong KM, Virmani AK, et al. Aberrant promoter methylation of multiple genes in non-small cell lung cancers. Cancer Res 2001; 61: 249-55.

46. Yang Y, Takeuchi S, Hofmann WK, et al. Aberrant methylation in promoter-associated $\mathrm{CpG}$ islands of multiple genes in acute lymphoblastic leukemia. Leuk Res 2006; 30: $98-102$.

47. Tanaka H, Shimada Y, Harada H, et al. Methylation of the 5' $\mathrm{CpG}$ island of the FHIT gene is closely associated with transcriptional inactivation in esophageal squamous cell carcinomas. Cancer Res 1998; 58: 3429-34.

48. Matsushita C, Yang Y, Takeuchi S, et al. Aberrant methylation in promoter-associated $\mathrm{CpG}$ islands of multiple genes in relapsed childhood acute lymphoblastic leukemia. Oncol Rep 2004; 12: 97-9.

49. Sobti RC, MalekZadeh K, Nikbakht M, et al. Hypermethylation-mediated partial transcriptional silencing of DAPkinase gene in bladder cancer. Biomarkers 2010; 15: 167-74.

50. Narayan G, Arias-Pulido H, Koul S, et al. Frequent promoter methylation of CDH1, DAPK, RARB, and HIC1 genes in carcinoma of cervix uteri: its relationship to clinical outcome. Mol Cancer 2003; 2: 24.

51. Chim CS, Wong SY, Pang A, et al. Aberrant promoter methylation of the retinoic acid receptor alpha gene in acute promyelocytic leukemia. Leukemia 2005; 19: 2241-6. 